\title{
PENGARUH NILAI EMOSIONAL, NILAI SOSIAL, NILAI KUALITAS DAN NILAI FUNGSIONAL TERHADAP KEPUTUSAN PEMBELIAN SEPEDA MOTOR MEREK TVS DI KOTA BENGKULU
}

\author{
Diah Khairiyah, Melda Yunita \\ Program Studi Manajemen Fakultas Ekonomi Universitas Muhammadiyah Bengkulu
}

\begin{abstract}
ABSTRAK
Diah Khairiyah, Melda Yunita; Tujuan dari penelitian ini adalah untuk mengetahui Pengaruh nilai emosional, nilai sosial, nilai kualitas, dan nilai fungsional terhadap keputusan pembelian sepeda motor tvs di kota bengkulu.Teknik sampel dalam penelitian ini sebanyak 30 orang dengan teknik pengumpulan data menggunakan kuisioner, analisis data yang digunakan dengan menggunakan metode regresi linear berganda .

Dari tabel Anova diperoleh nilai signifikan (sig) 0,000. Nilai signifikan dibandingkan pada alpa 0,05, dari hasil tersebut dapat diartikan nilai signifikan $0,000<0,05$, karena nilai signifikan 0,000 lebih kecil dari 0,05 maka dapat diartikan bahwa Ha diterima. Maka disimpulkan bahwa terdapat pengaruh yang signifikan diantara nilai nilai emosional (X1) ,nilai sosial (X2), nilai kualitas (X3), nilai fungsional (X4), terhadap nilai y terhadap keputusan pembelian.

Hasil t nilai signifikan (X $\mathrm{X}_{1}$ ) adalah 0,004 Faktor Nilai Sosial (X2) adalah 0,005, Faktor Nilai Kualitas (X3) adalah 0,009, dan Faktor Nilai Fungsional (X4) adalah 0,000. Jika nilai-nilai ini dibandingkan dengan pada alpha 0,05 hasilnya lebih kecil artinya Ha diterima berarti terdapat vpengaruh yang signifikan nilai nilai emosional (X1) ,nilai sosial (X2), nilai kualitas (X3), nilai fungsional (X4), terhadap keputusan pembelian $(\mathrm{Y})$.
\end{abstract}

\begin{abstract}
Diah Khairiyah, Melda Yunita; The purpose of this study was to know the effect of emotional value, social value, quality value and functional value to the purchasing decision of TVS motorcycle in Bengkulu city. The sample in this study using many as 30 persons data analysis using multiple linear regression method.

From the Anova table above obtained significant value (sig) 0,000. Significantly correlated to the alpha value of 0.05 , can be interpreted from the results of significant value $0.000<0.05$, due to the significant value of 0.000 is smaller than 0.05, it means that Ha is accepted. It was concluded that ha received means a significant difference between the value of $x$ to the $y$ value to the purchasing decision.

The results of significant value $t\left(X_{1}\right)$ is 0.004, Social Value Factor (X2) is 0.005, Factor Value Quality (X3) is 0.009 , and the Functional Rating Factor (X4) is 0.000. If these values correlated with the alpha of 0.05 means the result is smaller then $\mathrm{Ha}$ acceptable means there is significant influence value $(X)$ to the purchasing decision (Y).
\end{abstract}

Key Words: Consumer perception in purchase decision of TVS Motor Bike in Bengkulu CIty.

\section{LATAR BELAKANG}

Perkembangan usaha dewasa ini telah diwarnai dengan berbagai macam persaingan di segala bidang. Melihat kondisi tersebut menyebabkan pebisnis semakin dituntut untuk mempunyai strategi yang tepat dalam memenuhi target volume penjualan. Mengingat perkembangan teknologi yang makin dinamis, manusia dituntut dengan cepat dan tepat untuk bertindak agar tidak kalah bersaing. Menurut Kotler (2002:34) dalam meningkatkan persaingan masing-masing perusahaan harus dapat memenangkan persaingan tersebut dengan menampilkan produk yang terbaik dan dapat memenuhi selera konsumen yang selalu berkembang dan berubah-ubah sesuai dengan perilaku pembelian. Perilaku pembelian seseorang dapat dikatakan sesuatu yang unik, karena preferensi dan sikap terhadap obyek setiap orang berbeda. Selain itu konsumen berasal dari beberapa segmen, sehingga apa yang diinginkan dan dibutuhkan juga berbeda.

Menurut Peter dan Olson (2005),Perilaku konsumen sebagai interaksi dinamis dari pengaruh dan kesadaran, perilaku dan lingkungan dimana manusia melakukan pertukaran aspek hidupnya. Pengembangan model perilaku konsumen menurut Model Howard-Sheth dengan menetapkan tiga faktor yang berpengaruh terhadap perilaku konsumen. Faktor pertama yang berpengaruh pada konsumen adalah stimuli. Stimuli menunjukkan penerimaan informasi oleh konsumen dan pemprosesan informasi terjadi saat konsumen mengevaluasi informasi dari periklanan, teman atau dari pengalaman sendiri. 
Faktor kedua berasal dari hasil penelitian mengenai faktor-faktor yang mempengaruhi proses atau keputusan pembelian telah banyak dilakukan dan faktor Ketiga adalah perlu mengetahui sikap konsumen atas produk. Melalui riset ini akan dianalisis mengenai persepsi konsumen terhadap pembelian sepeda motor TVS, Alasan penulis mengambil jenis sepeda motor TVS karena jenis merek sepeda motor ini memiliki keunggulan dan paling banyak diminati atau dibeli oleh masyarakat. Melihat dari keunggulan sepeda motor TVS yang berbeda ini, maka perlu dilakukan penilaian mengenai persepsi konsumen dalam membeli sepeda motor. Faktor yang mempengaruhi keputusan konsumen dalam membeli sepeda motor dengan mengacu dari teori yang dikemukakan oleh Fandy Tjiptono, Yanto Chandra dan Anastasia Diana (2004), dimana faktor-faktor yang mempengaruhi keputusan konsumen dalam membeli sepeda motor adalah dilihat dari nilai kualitas, nilai emosional, nilai fungsional dan nilai sosial. Keempat variabel tersebut berpengaruh terhadap pembelian sepeda motor merek TVS di Bengkulu.

\section{LANDASAN TEORI}

Pembelian adalah serangkaian tindakan untuk mendapatkan barang dan jasa melalui pertukaran, dengan maksud untuk digunakan sendiri atau dijual kembali. Menurut sofjan assuari (2008) pembelian merupakan salah satu fungsi yang penting dalam berhasilnya berhasil suatu perusahaan. Fungsi ini dibebani tanggung jawab untuk mendapatkan kuantitas dan kualitas bahan-bahan yang tersedia pada waktu yang dibutuhkan dengan harga yang sesuai dengan harga yang berlaku. Pengawasan perlu dilakukan terhadap pelaksanaan fungsi ini, karena pembelian menyangkut investasi dana dalam persediaan dan kelancaran arus bahan kedalam pabrik.

\section{Pengertian Perilaku Konsumen}

Mangkunegara (2009) bahwa : "Perilaku konsumen sebagai tindakan-tindakan individu yang secara langsung terlibat dalam usaha memperoleh dan menggunakan barang-barang jasa ekonomis termasuk proses pengambilan keputusan yang mendahului dan menentukan tindakan-tindakan tersebut." Merujuk pada beberapa pengertian tentang perilaku konsumen, maka terlihat bahwa memahami perilaku konsumen bukanlah suatu pekerjaan yang mudah karena banyaknya variabel yang mempengaruhi dan variabel-variabel tersebut saling berinteraksi. Perilaku konsumen merupakan proses yang kompleks dan multi dimensional. Di dalam mempelajari perilaku konsumen ini pemasar tidak hanya berhenti pada perilaku konsumen semata saja namun juga perlu mengkaitkannya dengan strategi pemasaran yang akan disusunnya. Strategi pemasaran yang baik pada hakekatnya didasarkan pada apa yang diinginkan dan dibutuhkan konsumennya. Perusahaan yang mampu memahami perilaku konsumen akan mendapatkan keuntungan yang cukup besar karena dapat menyusun strategi pemasaran yang tepat yang dapat memberikan kepuasan yang lebih baik dibandingkan pesaing.

\section{Keputusan Pembelian}

Keputusan berarti pilihan, yaitu pilihan dari dua atau lebih kemungkinan. Namun, hampir tidak merupakan pilihan antara yang benar dan yang salah, tetapi yang justru sering terjadi ialah pilihan antara yang "hampir benar" dan yang "mungkin salah". Walaupun keputusan biasa dikatakan sama dengan pilihan, ada perbedaan penting di antara keduanya. Keputusan adalah "pilihan nyata" karena pilihan diartikan sebagai pilihan tentang tujuan termasuk pilihan tentang cara untuk mencapai tujuan itu, apakah pada tingkat perorangan atau pada tingkat kolektif. Keputusan kaitannya dengan proses merupakan keadaan akhir dari suatu proses yang lebih dinamis, yang diberi label pengambilan keputusan. Keputusan dipandang sebagai proses karena terdiri atas satu seri aktivitas yang berkaitan dan tidak hanya dianggap sebagai tindakan bijaksana.

Salusu (2003) mengemukakan bahwa: "Pengambilan keputusan ialah proses memilih suatu alternatif cara bertindak dengan metode yang efisien sesuai situasi". Selanjutnya Amirullah (2002) bahwa : "Pengambilan keputusan adalah suatu proses penilaian dan pemilihan dari berbagai alternatif sesuai dengan kepentingan-kepentingan tertentu dengan menetapkan suatu pilihan yang dianggap paling menguntungkan". Pengambilan keputusan mempunyai arti penting bagi maju mundurnya suatu organisasi, terutama karena masa depan suatu organisasi banyak ditentukan oleh pengambilan keputusan sekarang.

\section{Faktor-faktor yang Mempengaruhi Keputusan Pembelian}

Tjiptono, et al (2004), dimana faktor-faktor yang mempengaruhi keputusan konsumen dalam membeli sepeda motor adalah dilihat dari nilai kualitas, nilai emosional, nilai fungsional dan nilai sosial. Sejalan dengan teori yang dikemukakan oleh Tjiptono (2006) faktor-faktor yang mempengaruhi keputusan pembelian pelanggan adalah ikatan emosional yang terjalin antara pelanggan dan produsen 
setelah pelanggan menggunakan produk dan jasa dari perusahaan dan mendapati bahwa produk atau jasa tersebut memberi nilai tambah. Dimensi nilai terdiri dari 4, yaitu :

1. Nilai emosional, utilitas yang berasal dari perasaan atau afektif atau emosi positif yang ditimbulkan dari mengkonsumsi produk. Kalau konsumen mengalami perasaan positif (positive feeling) pada saat membeli atau menggunakan suatu merek, maka merek tersebut memberikan nilai emosional. Pada intinya nilai emosional berhubungan dengan perasaan, yaitu perasaan positif apa yang akan dialami konsumen pada saat membeli produk.

2. Nilai sosial, utilitas yang didapat dari kemampuan produk untuk meningkatkan konsep diri-sosial konsumen. Nilai sosial merupakan nilai yang dianut oleh suatu konsumen, mengenai apa yang dianggap baik dan apa yang dianggap buruk oleh konsumen

3. Nilai kualitas, utilitas yang didapat dari produk karena reduksi biaya jangka pendek dan biaya jangka panjang.

4. Nilai fungsional adalah nilai yang diperoleh dari atribut produk yang memberikan kegunaan (utility) fungsional kepada konsumen nilai ini berkaitan langsung dengan fungsi yang diberikan oleh produk atau layanan kepada konsumen.

\section{Pengaruh Nilai Emosional terhadap Keputusan Pembelian}

David Aaker (1996) mengatakan nilai ekspresi diri merupakan bagian dari nilai emosional. Perbedaan antara nilai emosional dengan nilai ekspresi diri adalah nilai emosional berkaitan dengan perasaan bahagia, nyaman, dan bangga. Sedangkan nilai ekspresi diri berkaitan dengan bagaimana perasaan seseorang mengenai dirinya di mata orang lain maupun diri orang itu sendiri. Nilai emosional berpusat pada diri sendiri sedangkan nilai ekspresi diri berpusat pada publik. Nilai ekspresi diri berkaitan dengan bagaimana pandangan orang lain terhadap seseorang. Contohnya yaitu ekspresi diri yang "Ceria" yang diekpresikan oleh minuman Fanta.

\section{Pengaruh Nilai Sosial terhadap Keputusan Pembelian}

Suminto (2000) bahwa kebudayaan sebagai suatu konsep yang luas, yang di dalamnya tercakup adanya sistem dari pranata nilai yang berlaku termasuk tradisi yang mengisyaratkan makna pewarisan norma-norma, kaidah-kaidah, adat istiadat dan harta-harta cultural. Berdasarkan hasil penelitian terdahulu diketahui bahwa dengan apa yang diungkapkan dalam penelitian Choi et al. (2013) bahwa nilai sosial berpengaruh signifikan terhadap niat pembelian ulang.

\section{Pengaruh Nilai Kualitas terhadap Keputusan Pembelian}

Kualitas produk didefinisikan sebagai persepsi pelanggan terhadap keseluruhan kualitas atau keunggulan suatu produk atau jasa layanan berkaitan dengan apa yang diharapkan oleh pelanggan (Durlanto, Sugiarto \& Sitinjak, 2001). Karena persepsi terhadap kualitas merupakan persepsi dari pelanggan, maka tidak dapat ditentukan secara obyektif. Persepsi pelanggan akan melibatkan apa yang penting agar pelanggan karena setiap pelanggan memiliki kepentingan yang berbeda-beda terhadap suatu produk atau jasa.

\section{Pengaruh Nilai Fungsional terhadap Keputusan Pembelian}

Besterfield, et al. (1999, dalam Simamora, 2002) melihat kualitas dari perbandingan antara performa dan harapan. Bila performa dapat memenuhi atau melampaui harapan, maka produk tersebut berkualitas. Sebaliknya, produk yang performanya di bawah harapan maka produk tersebut tidak berkualitas. Juga perlu diingat bahwa performa dan harapan ditentukan oleh konsumen sesuai dengan persepsi mereka. Berdasarkan hasil penelitian diketahui adanya pengaruh yang positif dan signifikan antara nilai fungsional (harga) terhadap niat pemanfaatan ulang pelayanan rawat jalan. Hasil yang diperoleh sejalan dengan penelitian Yang et al. (2004) yang menyebutkan bahwa harga sebagai moderator untuk mengahasilkan kepuasan dan loyalitas (memanfaatkan ulang). Dari sudut pandang konsumen, harga digunakan sebagai indikator nilai, jika harga dihubungkan dengan manfaat yang dirasakan atas suatu barang atau jasa. Jawaban responden menunjukkan bahwa biaya yang wajar, ekonomis serta sebanding dengan pelayanan yang diterimanya berpengaruh pada niat untuk menggunakan ulang pelayanan. 


\section{Kerangka Analisis}

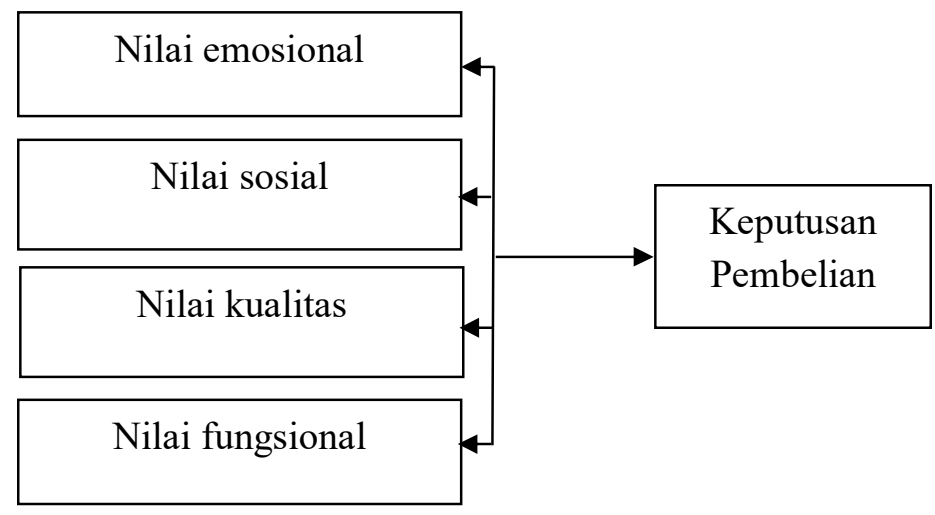

Gambar 1. Kerangka Analisis

\section{METODE PENELITIAN}

Untuk memperoleh data serta keterangan yang diperoleh dalam penelitian ini, penulis menggunakan teknik pengumpulan data melalui :

1. Interview yakni teknik pengumpulan data dengan cara mengadakan tanya jawab atau interview dengan konsumen pemakai sepeda motor TVS di Bengkulu

2. Kuesioner yakni teknik pengumpulan data dengan menyebarkan sejumlah angket atau pertanyaanpertanyaan mengenai persepsi konsumen terhadap keputusan pembelian sepeda motor merek TVS di bengkulu.

\section{Analisis Regresi Linier Berganda}

Analisis kuantitatif dengan menggunakan alat analisis regresi berganda adalah suatu analisis yang digunakan oleh peneliti, bila peneliti bermaksud meramalkan bagaimana keadaan (naik turunnya) variabel dependen, bila dua atau lebih variabel independent sebagai faktor prediktor, sebagaimana dikutip dari Sugiyono (2013, hal. 251) dengan menggunakan rumus :

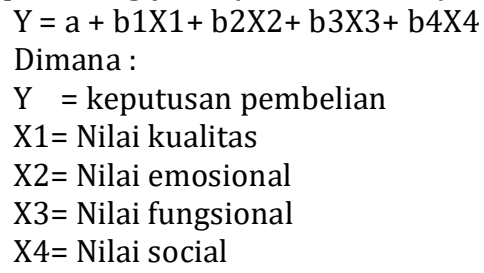

\section{Koefisien Determinasi}

Analisis koefisien determinasi adalah suatu alat ukur yang digunakan untuk mengetahui seberapa besar sumbangan atau kontibusi variabel pengaruh dengan menggunakan rumus sebagai berikut:

$$
\mathrm{R}^{2}=\sqrt{\frac{b_{\Sigma} x Y+b_{X Y}}{Y^{2}}} \quad \text { (sugiono,2013) }
$$

\section{Uji f dan Uji t}

a. Uji F statistik

Uji F statistik digunakan untuk mengetahui apakah variabel independen (X), secara simultan berpengaruh terhadap variabel dependen (Y). Rumus uji F seperti yang dikemukakan oleh sugiyono (2013: 297) sebagai berikut:

$$
\begin{aligned}
& \left.\mathrm{F}_{\text {sig }}=\frac{\mathrm{R}^{2} / \mathrm{k}}{\left(1-\mathrm{R}^{2}\right) /(\mathrm{n}-\mathrm{k}-1)} \text { (Sugiyono, } 2013: 297\right) \\
& \text { Keterangan: } \\
& \mathrm{F}_{\text {sig }}=\text { Nilai } \mathrm{F}_{\text {sig }} \\
& \mathrm{R}^{2} \quad=\text { Nilai koefisien korelasi berganda } \\
& \mathrm{K} \quad=\text { Jumlah variabel } \\
& \mathrm{n} \quad=\text { Jumlah Anggota sampel }
\end{aligned}
$$


Dengan kriteria pengujian sebagai berikut :

a. $\mathrm{F}_{\text {Sig }}>0,05$ berarti tidak ada pengaruh yang signifikan antara variabel $(\mathrm{X})$ terhadap variabel dependen(Y)

b. $\mathrm{F}_{\text {sig }}<0,05$ berarti ada pengaruh yang signifikan antara variabel $(\mathrm{X})$ terhadap Variabel $(\mathrm{Y})$

b. Uji t statistik

Uji $\mathrm{t}$ statistik digunakan untuk menguji apakah variabel independen $(\mathrm{X})$, secara parsial berpengaruh terhadap variabel dependen(Y).

$$
\begin{aligned}
& \mathrm{t}=\frac{\overline{\mathrm{X}}-\mu_{0}}{\sqrt[S]{\mathrm{n}}} \text { (Sugiyono, } 2013: \text { 280) } \\
& \text { Keterangan : } \\
& \mathrm{t} \quad=\text { nilai t yang dihitung } \\
& \overline{\mathrm{X}} \quad=\text { nilai rata-rata } \\
& \mu_{0} \quad=\text { nilai yang dihipotesiskan } \\
& \mathrm{S} \quad=\text { simpangan baku sampel } \\
& \mathrm{n} \quad=\text { jumlah anggota sampel }
\end{aligned}
$$

dengan kriteria pengujian sebagai berikut:

a. $t_{\text {sig }}<0.05$ maka Ha di terima dan Ho ditolak berarti ada pengaruh yang siknifikan antara variabel (X) terhadap variabel (Y)

b. $t_{\text {sig }}>0,05$ maka Ho diterima Ha ditolak berarti tidak ada pengaruh yang siknifikan anatara variabel

(X) terhadap variabel (Y).

\section{HASIL PENELITIAN DAN PEMBAHASAN}

PT TVS Motor Company Indonesia yang merupakan bagian dari TVS Motor Company dari India, salah satu perusahaan manufaktur roda dua terbesar di dunia. TVS merupakan pusat yang ditunjuk di kawasan Asia Tenggara untuk membangun fasilitas manufaktur terintegrasi yang termasuk didalamnya: produksi mesin, produksi kendaraan, pengetesan dan fasilitas pengecatan yang berlokasi di kawasan industry Surya Cipta di Karawang Jawa Barat dengan kapasitas produksi 300,000 sepeda motor. PT TVS Motor Company Indonesia berkomitmen menyediakan proses manufaktur kelas dunia berkualitas ekspor dari fasilitas produksi TVS di Indonesia dan memiliki kandungan lokal $65 \%$ didalam komponen sepeda motor yang termasuk didalamnya: plastik, fabrikasi dan part aluminium. TVS telah menjadi anggota AISI atau Asosiasi Industri Sepeda Motor Indonesia sejak Maret 2010.Tahap pertama dari investasi TVS adalah sebesar 50 juta US Dollar dengan tambahan 75 juta US Dollar untuk tahap berikutnya. Saat ini, lebih dari 50.000 orang telah menggunakan sepeda motor TVS di jalanan Indonesia. Sudah menjadi kebiasaan dalam hal kualitas terdepan dan membantu memberikan pemenuhan kebutuhan sepeda motor rakyat Indonesia yang terus berkembang, dan jaringan sales, service dan sparepart TVS akan terus menjangkau pelanggan lebih luas lagi di kawasan Asia Tenggara.

\begin{tabular}{|c|c|c|c|c|c|c|}
\hline \multirow{2}{*}{\multicolumn{2}{|c|}{ Model }} & \multicolumn{2}{|c|}{ Unstandardized Coefficients } & $\begin{array}{l}\text { Standardized } \\
\text { Coefficients }\end{array}$ & \multirow[b]{2}{*}{$\mathrm{T}$} & \multirow[b]{2}{*}{ Sig. } \\
\hline & & $\mathrm{B}$ & Std. Error & Beta & & \\
\hline \multirow[t]{5}{*}{1} & (Constant) & .357 & .565 & & .278 & .784 \\
\hline & $\mathrm{X} 1$ & .176 & .101 & .284 & 1.743 & .004 \\
\hline & $\mathrm{X} 2$ & .133 & .072 & .227 & 1.861 & .005 \\
\hline & X3 & .019 & .043 & .033 & 1.947 & .009 \\
\hline & $\mathrm{X} 4$ & .640 & .098 & .866 & 2.519 & .000 \\
\hline
\end{tabular}

\section{Uji Koefisien Regresi Linier Berganda}

1. Analisis Regresi Linier berganda

Hasil analisis regresi berganda dengan menggunakan program SPSS, mengenai pengaruh keselamatan kerja dan kesehatan kerja terhadap produktivitas karyawan, dapat dilihat pada table 4.10

Tabel 1. Analisis Regresi Linier Berganda Coefficients $^{a}$

a. Dependent Variable: $Y$

Maka di dapat persamaan regresi linier berganda sebagai berikut : 
$\mathrm{Y}=0,357+0,176(\mathrm{X} 1)+0,133(\mathrm{X} 2)+0,019(\mathrm{X} 3)+0,640(\mathrm{X} 4)$

Persamaan tersebut dapat dijelaskan sebagai berikut:

1) Nilai konstanta 0,357 mempunyai arti bahwa apabila Nilai Emosional (X1), Nilai Sosial (X2), Nilai Kualitas (X3) dan Nilai Fungsional (X4) sama dengan nol, maka Keputusan pembeli akan bertambah $0,357$.

2) jika nilai emosional (X1) naik satu-satuan maka keputusan pembelian naik senilai = 0,176 mempunyai arti bahwa nilai emosional mempunyai pengaruh positif terhadap keputusan pembelian sepeda motor merek tvs di kota bengkulu.

3) jika nilai sosial (X2) naik satu-satuan maka keputusan pembelian naik senilai $=0,133$ mempunyai arti bahwa nilai emosional mempunyai pengaruh positif terhadap keputusan pembelian sepeda motor merek tvs di kota bengkulu

4) jika nilai kualitas (X3) naik satu-satuan maka keputusan pembelian naik senilai = 0,019 mempunyai arti bahwa nilai emosional mempunyai pengaruh positif terhadap keputusan pembelian sepeda motor merek tvs di kota bengkulu

5) jika nilai kualitas (X4) naik satu-satuan maka keputusan pembelian naik senilai $=0,640$ mempunyai arti bahwa nilai emosional mempunyai pengaruh positif terhadap keputusan pembelian sepeda motor merek tvs di kota bengkulu

\section{Pembahasan}

\section{Nilai Emosional}

Nilai emosional, utilitas yang berasal dari perasaan atau afektif atau emosi positif yang ditimbulkan dari memproduksi produk. Kalau konsumen mengalami perasaan positif (positive feeling) pada saat membeli atau menggunakan suatu merek, maka merek tersebut memberikan nilai emosional. Pada intinya nilai emosional berhubungan dengan perasaan, yaitu perasaan positif apa yang akan dialami konsumen pada saat membeli produk.

Jika di lihat dari nioai emosional bisa diambil kesimpulan bahwa ketika permintaan konsumen untuk membeli produk motor merek tvs maka segi nproduksi akan bertambah. Lebih terlihat peningkatan secara drastis dikarnakan nilai emosional untuk memenuhi nilai konsumen, serta dari tingkat emosional konsumen bisa kita pergunakan untik menarik kesimpulan produk tvs yang kita produksi maju atau menglami penurunan.

\section{Nilai sosial}

Nilai sosial, utilitas yang didapat dari kemampuan produk untuk meningkatkan konsep diri-sosial konsumen. Nilai sosial merupakan nilai yang dianut oleh suatu konsumen, mengenai apa yang dianggap baik dan apa yang dianggap buruk oleh konsumen. Jika dilihat dari nilain sosial merupakan tolak ukur yang dilihat dari tanggapan-tanggapan para konsumen yang sudah membeli produk tvs yang diproduksi baik berupa tanggapan merasa puas maupun tidak puas, serta sebagai gambaran bagi perusahaan maupun masyarakat terhadap produk tvs yang di produksi bisa diterima atau tidak.

\section{Nilai kualitas}

Nilai kualitas, utilitas yang didapat dari produk karena reduksi biaya jangka pendek dan biaya jangka panjang. Nilai koalitas yang bisa dilihat atau dipergunakan ketika produk tvs melakukan produksi selanjutnya atau nilai perbandingan yang bisa diperlakukan terhadap produk lain (dalam hal kualitas produk), serta sebagai pertimbangan perusahaan dalam melakukan pengeluaran biaya untuk lebih memproduksi produk tvs yang lebih berkualitas selanjutnya, dan apabila nilai kualitasnya bagus di mata para konsumen maka produk tersebut akan semakin meningkat dalam segi memproduksi.

\section{Nilai fungsional}

Nilai fungsional adalah nilai yang diperoleh dari atribut produk yang memberikan kegunaan (utility) fungsional kepada konsumen nilai ini berkaitan langsung dengan fungsi yang diberikan oleh produk atau layanan kepada konsumen. Dimana nilai fungsional yang bisa dilihat sejauh mana tingkat produksi kita bisa dinikmati oleh para konsumen dan sejuhmana fungsi tersebut masih dipergunakan dalam memenuhi keinginan konsumen selanjutnya, dan apakah nilai fungsional sudah berjalan baik atu tidak. Maka perusahaan harus mampu menciptakan produk dalam nilai fungsional yang bermutu agar para konsumen masih percaya terhadap prok tersebut.

Dari hasil uji validitas dapat dilihat bahwa 14 butir pertanyaan yang ada memenuhi uji validitas atau valid. Syarat untuk memenuhi kevalidan adalah bila nilai korelasi rhitung > rkritis dimana nilai rkritis sama dengan 0,3 atau lebih.

Berdasarkan hasil uji realibilitas diketahui bahwa nilai Alpha cronbach $(\alpha)$ melebihi batas minimum $\boldsymbol{\alpha}(=0,6)$ yaitu sebesar X1 $=0,761, \mathrm{X} 2=0,756, \mathrm{X} 3=0,727, \mathrm{X} 4=0,717$ dan Y $=0,655$. Alpha 
cronbach $(\boldsymbol{\alpha})$ untuk semua variabel yang diperoleh lebih dari 0,6 , hal ini menunjukan semua pertanyaan reliable.

\section{KESIMPULAN}

1. Hasil uji hipotesis secara parsial bahwa $t_{\text {sig }} \mathrm{X} 1=0,004<0.05, \mathrm{t}_{\text {sig }} \mathrm{X} 2=0,005<0,05, \mathrm{t}_{\text {sig }} \mathrm{X} 3=0,009$ $<0,05, \mathrm{t}_{\text {sig }} \mathrm{X} 4=0,000<0,05$, maka disimpulkan bahwa ha diterima berarti terdapat pengaruh signifikan diantara nilai $\mathrm{X}$ terhadap nilai keputusan pembelian (Y).

2. Dan hasil uji hipotesis secara simultan bahwa $F_{S i g} 0,000<0,05$, maka disimpulkan bahwa ha diterima berarti terdapat pengaruh signifikan diantara nilai $\mathrm{X}$ terhadap nilai keputusan pembelian (Y).

3. Dari hasil analisis regresi linear berganda di dapat persamaan regresi linier berganda sebagai berikut : $Y=0,357+0,176(X 1)+0,133(X 2)+0,019(X 3)+0,640(X 4)$. Persamaan tersebut berarti Nilai konstanta 0,357 mempunyai arti bahwa apabila Nilai Emosional (X1), Nilai Sosial (X2), Nilai Kualitas (X3) dan Nilai Fungsional (X4) sama dengan nol, maka Keputusan pembeli akan bertambah 0,357 .

\section{DAFTAR PUSTAKA}

Aaker \& David. (1996). Manajemen Equitas Merek. Jakarta: Spectrum Mitra Utama Assauri, Soyjan. 2008. Manajemen Produksi dan Operasi. Jakarta: LPFEUI.

Bilson Simamora, 2002, Panduan Riset Perilaku Konsumen, Surabaya: Pustaka Utama.

Choi, et al, 2013. An analysis of Australian company carbon emission disclosures. Pacific Accounting Review, Vol. 25 No. 1, 58-79

Durianto,Sugiarto dan Tony Sitinjak, 2001. Strategi Menaklukkan Pasar Melalui. Riset Ekuitas dan Perilaku Merek, PT. Gramedia Pustaka

Kotler, Philip, 2002, Manajemen Pemasaran, Jilid 1, Edisi Milenium, Jakarta, Prehallindo.

Mangkunegara, Anwar Prabu, 2009. Perilaku Konsumen, Edisi Revisi, Cetakan Kedua, Refika Aditama, Bandung

Salusu, I, 2003, Pengambilan Keputusan Stratejik Untuk Organisasi Publik Dan Organisasi Nonprofit, penerbit: PT. Grasindo, Jakarta Amirullah (2002, hal. 61)

Sayuti, Suminto. 2000. Kajian Fiksi. Yogyakarta: Gama Media

Sugiyono, 2013. Metode Penelitian Manajemen. Bandung: Alvabeta

Tjiptono, Fandy, Yanto Chandra, dan Anastasia Diana (2004). Marketing Scale, Edisi Satu, Yogyakarta: Andi

Tjiptono, Fandy, 2006, Pemasaran Jasa, edisi pertama, cetakan kedua, penerbit : Bayumedia Publishing, Malang 